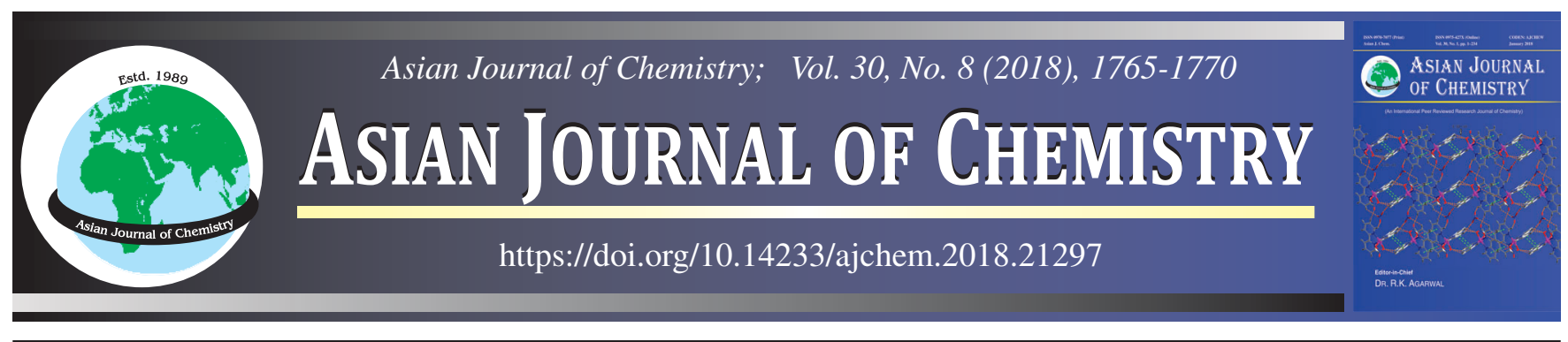

\title{
Synthesis, in vitro and Molecular Docking Studies of 1-(3,4-Dimethoxy-phenyl)-5-(4-hydroxy- 3-methoxy-phenyl)-penta-1,4-dien-3-one as New Potential Anti-inflammatory
}

\section{Mario Rowan Sohilait ${ }^{1,2, *}$, Harno Dwi Pranowo ${ }^{2}$ and Winarto Haryadi ${ }^{2}$}

${ }^{1}$ Department of Chemistry, Faculty of Mathematics and Natural Sciences, Pattimura University, Jl.Ir.M. Putuhena, Kampus Poka, Ambon 97233, Indonesia

${ }^{2}$ Department of Chemistry, Faculty of Mathematics and Natural Sciences, Universitas Gadjah Mada, Jl. Sekip Utara, Yogyakarta 55281, Indonesia

*Corresponding author: E-mail: rio.rowan@gmail.com

Synthesis of new asymmetrical curcumin analogue of 1-(3,4-dimethoxy-phenyl)-5-(4-hydroxy-3-methoxy-phenyl)-penta-1,4-dien-3-one via condensation reaction between vanillinacetone and veratraldehyde in ethanol has been performed. The in vitro anti-inflammatory activities of the synthesized compounds showed excellent anti-inflammatory activity. In vitro anti-inammatory activity by using inhibition of albumin denaturation technique compared to standard dichlorofenac. Molecular docking studies were performed, where docking of the compound into 6COX active site suggested that it could exert its anti-inflammatory potential by cyclooxygenase inhibition.

Keywords: Curcumin analogues, Anti-inflammatory, Molecular docking, Synthesis, in vitro.

\section{INTRODUCTION}

Inflammation is a localized physical condition with heat, swelling, redness and usually pain. It is mediated by the release of proinflammatory mediators (bradykinin and cytokines), which in turn increases the rate of prostaglandin synthesis [1,2]. Nonsteroidal anti-inflammatory drugs (NSAIDs) inhibit the biosynthesis of prostaglandins by inhibiting cyclooxygenases (COXs). It exists in two isoforms i.e., a constitutive form (COX-1) and an inducible form (COX-2) [3,4]. COX-1 enzyme is responsible for maintenance of gastric integrity and kidney function [5-7] whereas COX-2 is involved in the inflammation and pain $[8,9]$. All classical NSAIDs, such as aspirin and indomethacin are non selective inhibitors for both COX-1 and COX-2, but bind more tightly to COX-1. In order to prevent or decrease these side effects, a current strategy consists of designing selective COX-2 inhibitors with an improved gastric safety profile [10,11].

Curcuminoids exhibited many interesting biological activities [12], for example, antioxidant activity [13,14], antiinflammatory activity $[15,16]$, anticancer activity $[13,17,18]$, antiprotozoal activity [19] and anti-HIV activity [20]. On the other hand, curcumin analogue such as modification of the dienone functional group curcumin into monoketone and side chain of aromatic ring with symmetrical or asymmetrical substituents possessed structural features which conferred potential biological activity and pharmaceutical use $[21,22]$.
Curcumin, a well-known acyclic diarylheptanoid, has been identified as the major constituent in turmeric and it has been known for some time that curcuminoids have been used as a natural food additive. It belongs to the group of $\beta$-diketones and exhibits tautomerism between enol- and keto-structures. It has attracted special attention due to its potent pharmocalogical activities such as to protect cells from $\beta$-amyloid insult in Alzheimer's disease [23] and cancer preventive properties [24]. Biological activities of curcumin chelated to metal ions as well as antioxidant effects of curcumin are also well documented in literature [25]. The enol form is characterized by a strong intra-molecular hydrogen bond. When the enol group forms the intra-molecular hydrogen bond, the $\beta$ diketone undergoes changes towards the total $\pi$-system delocalization [26]. There is a strong correlation between the $\pi$-system delocalization and the strengthening of the intramolecular hydrogen bond. Moreover, in solution curcumin can form inter-molecular $\mathrm{H}$-bonds with the solvent molecules and this strongly influences its physicochemical properties. The chemopreventive effects of curcumin have been attributed to various biological properties, including neutralization of carcinogenic free radicals [27] and anti-angiogenesis action, which limits the blood supply to rapidly growing malignant cells $[28,29]$. However, the nature of many biological properties of curcumin remains unclear; therefore the investigation of the structure and reactivity of this prolific medicinal agent 
is important. A photolysis study by Jovanovic et al. [30] attributes the antioxidant mechanism of curcumin to intramolecular $\mathrm{H}$-atom in the keto-enolic group. A theoretical study by Balasubramanian suggests that the keto-enolic form of curcumin may be responsible for the inhibition of $\beta$-amyloid aggregation [31].

During the last decade, synthetic modifications of curcumin, which were aimed at enhancing its bioactivities, have been intensively studied. One sustainable strategy for green synthesis of organic compounds is microwave irradiation. Since, microwaves will not affect molecular structure in the excitation of molecules, the effect of microwave absorption is purely kinetic. Compared to traditional methods, microwave synthesis is more convenient to synthesize and can be carried out in higher yields in short reaction times under mild reaction conditions. In the present study, we report the synthesis of asymmetrical curcumin analogues under microwave irradiation.

Molecular docking study further helped in supporting the observed COX-2 selectivity. Molecular docking study of 5-nitro-2-(3,4,5-trimethoxybenzyl)-isoindoline-1,3-dione into the active site of COX-2 revealed a similar binding mode to SC-558, a selective COX-2 inhibitor. Docking study showed that the methoxy moeities of 5-nitro-2-(3,4,5-trimethoxybenzyl)-isoindoline-1,3-dione inserted deep inside the $2^{\circ}$ pocket of the COX-2 active site, where the O-atoms of such groups underwent an H-bonding interaction with $\mathrm{His}^{90}$ (3.02 $\AA$ ) and $\operatorname{Arg}^{513}(1.94,2.83 \AA)$ [32]. The interaction with amino acid Ser530 is important for enzyme inhibitory activity and is well exemplified by the binding interaction of aspirin with COX-2 [33]. Active site amino acid residues Ser530, Met522, Tyr385, Arg513, Phe518, His90 and Arg120 surrounded the phenyl rings of curcumin analogues [34]. The scoring function and a number of hydrogen bondings formed with the surrounding amino acids are used to predict their binding modes. The level of COX-2 inhibition of compound prompted us to perform molecular docking studies to understand the ligand-protein interactions in detail.

The transformation of the $\beta$-diketone structure of curcumin as a monocarbonyl curcumin significantly increases its stability. As a result, the design, synthesis and evaluation of its pharmacological activity of single carbonyl curcumin analogues has become a research focus. The reported monocarbonyl curcumin analogues are mainly about symmetric curcumin analogues, rarely are about asymmetric monocarbonyl curcumin analogues. This paper described the synthesis and anti-inflammatory activity of new asymmetric monocarbonyl curcumin analogues and the molecular docking studies.

\section{EXPERIMENTAL}

Melting points $\left({ }^{\circ} \mathrm{C}\right)$ were recorded using a Fisher Scientific Digital melting point apparatus and are uncorrected. Infrared spectra were obtained on a Prestige-21 Shimadzu FTIR spectrophotometer. ${ }^{1} \mathrm{H}$ and ${ }^{13} \mathrm{C}$ NMR were recorded on a JEOL JNMECZ 500R spectrophotometer at 500 and $125 \mathrm{MHz}$, respectively in DMSO- $d_{6}$ and $\mathrm{CDCl}_{3}$ as the solvent. Mass spectra (MS) were obtained on a Shimadzu MS-QP 2010S. Column chromatography purifications were carried out on silica gel
60 (E. Merck, 70-230 mesh). Chromatographic purity by HPLC (Shimadzu LC-20AD prominence) was determined by using area normalization method and the condition specified in each case: column, mobile phase (range used), flow rate, detection wavelength and retention times. Microwave irradiation is performed by a conventional (unmodified) domestic microwave oven equipped with a turntable (SHARP, R-268R, 230-240 V $\sim 50 \mathrm{~Hz}, 800 \mathrm{~W}, 2450 \mathrm{MHz}$ ).

Synthesis of 4-(4-hydroxy-3-methoxy-phenyl)-but-3en-2-one: A mixture of the vanillic aldehyde $(0.2 \mathrm{mmol})$ and acetone $(0.6 \mathrm{mmol})$ in methanol $(20 \mathrm{~mL})$ was added potassium hydroxide ( $1 \mathrm{M}$ in water, $5 \mathrm{~mL}$ ) and the the mixture was placed in a microwave oven. The resulting precipitate was removed by filtration, washed with cold ethanol and purified by recrystallization from ethanol. Light yellow powder, yield $92 \%$, m.p. 128-130 ${ }^{\circ} \mathrm{C} ;{ }^{1} \mathrm{H}$ NMR $\left(\mathrm{CDCl}_{3}\right): \delta 2.33(\mathrm{~s}, 3 \mathrm{H}), 3.89(\mathrm{~s}, 3 \mathrm{H})$, $6.059(\mathrm{~s}, 1 \mathrm{H}, \mathrm{OH}), 6.57(\mathrm{~d}, 1 \mathrm{H}, \mathrm{Ar}), 6.91(\mathrm{~d}, 1 \mathrm{H}, \mathrm{Ar}), 7.02(\mathrm{~d}$, $1 \mathrm{H}, J=6.4 \mathrm{~Hz}), 7.06(\mathrm{~d}, 1 \mathrm{H}, \mathrm{Ar}), 7,43(\mathrm{~d}, 1 \mathrm{H}, J=6.4 \mathrm{~Hz}) ;{ }^{13} \mathrm{C}$ NMR $\left(\mathrm{CDCl}_{3}\right): 27.47\left(\mathrm{CH}_{3}\right), 56.14\left(\mathrm{OCH}_{3}\right), 109.54(\mathrm{Ar})$, $115.04(\mathrm{Ar}), 123.70(\mathrm{Ar}), 125.13(\mathrm{Ar}), 127.07(\mathrm{CH}=\mathrm{CH})$, $144.00(\mathrm{CH}=\mathrm{CH}), 147.11(\mathrm{C}-\mathrm{OH}), 148.51\left(\mathrm{C}-\mathrm{OCH}_{3}\right), 198,69$ $(\mathrm{C}=\mathrm{O})$; HPLC $100 \%$, column: Shim-Pack VP-OPS $(250 \times$ 4.6) $\mathrm{mm}$, mobile phase: methanol/acetonitrile (70:30), flow rate $1.0 \mathrm{~mL} / \mathrm{min}, \mathrm{UV} 268 \mathrm{~nm}$, retention time $6.013 \mathrm{~min} ; \mathrm{C}_{11} \mathrm{H}_{12} \mathrm{O}_{3}$ : $\mathrm{m} / \mathrm{z} 192[\mathrm{M}+\mathrm{H}]^{+}$.

Synthesis of 1-(3,4-dimethoxy-phenyl)-5-(4-hydroxy3-methoxy-phenyl)-penta-1,4-dien-3-one: A mixture of the veratraldehyde $(0.2 \mathrm{mmol})$ and the vanillinacetone $(0.2 \mathrm{mmol})$ were dissolved in $15 \mathrm{~mL}$ of ethanol. Into this solution $3 \mathrm{~mL}$ of a $1 \mathrm{M} \mathrm{KOH}$ solution in water was then added drop wise over several seconds and the mixture was placed in a microwave oven. The precipitate was washed with cold ethanol and dried in vacuum. The solid was purified by chromatography over silica gel using $\mathrm{CH}_{2} \mathrm{Cl}_{2} / \mathrm{CH}_{3} \mathrm{OH}(9: 1)$ as the eluent to yield compounds. Yellow powder, yield $81 \%$, m.p. $189-191{ }^{\circ} \mathrm{C}$; IR $(\mathrm{KBr}$, $\left.v_{\max }, \mathrm{cm}^{-1}\right): 3458(-\mathrm{OH}), 3005$ (CH-aromatic), $2835(\mathrm{CH}-$ aliphatic) $1643(\mathrm{C}=\mathrm{O}), 1620(\mathrm{C}=\mathrm{C}), 1581(\mathrm{Ar}-\mathrm{H}), 1267$ $\left(-\mathrm{OCH}_{3}\right) ;{ }^{1} \mathrm{H}$ NMR (DMSO- $\left.d_{6}\right): \delta 3.39(\mathrm{~s}, 3 \mathrm{H}), 3.85(\mathrm{~d}, 6 \mathrm{H})$, $4.12(\mathrm{~d}, 1 \mathrm{H}), 6.84(\mathrm{~d}, 1 \mathrm{H}, \mathrm{Ar}), 7.01(\mathrm{~d}, 1 \mathrm{H}, \mathrm{Ar}), 7.20(\mathrm{dd}, 1 \mathrm{H}$, Ar), 7.29 (d, 1H, Ar), 7.40 (d, 1H, Ar), 7.66 (d, CH=CH, $J=$ $16.2 \mathrm{~Hz}), 7.70(\mathrm{~d}, \mathrm{CH}=\mathrm{CH}, J=16.2 \mathrm{~Hz}), 8.01(\mathrm{C}=\mathrm{O}) ;{ }^{13} \mathrm{C}$ NMR (DMSO- $\left.d_{6}\right): 48.64\left(\mathrm{OCH}_{3}\right), 55.58\left(\mathrm{OCH}_{3}\right), 55.63$ $\left(\mathrm{OCH}_{3}\right), 55.73(\mathrm{Ar}), 110.48(\mathrm{Ar}), 111.40(\mathrm{Ar}), 111.64(\mathrm{Ar})$, $115.70(\mathrm{Ar}), 122.96(\mathrm{Ar}), 123.21(\mathrm{Ar}-\mathrm{CH}=), 123.47(\mathrm{Ar}-\mathrm{CH}=)$, $123.91(\mathrm{CH}=\mathrm{CH}), 126.35(\mathrm{CH}=\mathrm{CH}), 127.63\left(\mathrm{OCH}_{3}\right), 142.41$ $\left(\mathrm{OCH}_{3}\right), 143.04\left(\mathrm{OCH}_{3}\right), 148.01\left(\mathrm{C}_{\mathrm{Ar}}-\mathrm{OH}\right), 149.03(\mathrm{CH}=\mathrm{CH})$, $149.51(\mathrm{CH}=\mathrm{CH}), 151.95(\mathrm{C}=\mathrm{O})$; HPLC $100 \%$, column: ShimPack VP-OPS $(250 \times 4.6) \mathrm{mm}$, mobile phase: methanol/acetonitrile (70:30), flow rate $1.0 \mathrm{~mL} / \mathrm{min}$, UV $268 \mathrm{~nm}$, retention time $6.502 \mathrm{~min} ; \mathrm{C}_{20} \mathrm{H}_{20} \mathrm{O}_{4}: \mathrm{m} / \mathrm{z}, 324[\mathrm{M}+\mathrm{H}]^{+}$.

Anti-inflammatory activity: Methods of Priya et al. [35], Suresh Kumar et al. [36] and Sahoo et al. [37] followed with minor modification. The reaction mixture was consisting of test compound at different concentrations and $1 \mathrm{~mL}$ of $1 \mathrm{mM}$ albumin solution in $0.2 \mathrm{M}$ phosphate buffer. $\mathrm{pH}$ of the reaction mixture was adjusted using small amount of $1 \mathrm{~N} \mathrm{HCl}$. The samples were incubated at $37{ }^{\circ} \mathrm{C}$ for $15 \mathrm{~min}$ and then heated at $70{ }^{\circ} \mathrm{C}$ for $15 \mathrm{~min}$. After cooling the samples, the turbidity 
was measured spectrophotometrically at $660 \mathrm{~nm}$. The experiment was performed in triplicate. Per cent inhibition of protein denaturation was calculated as follows:

$$
\text { Inhibition }(\%)=\frac{\mathrm{Abs}_{\text {sample }}-\mathrm{Abs}_{\text {control }}}{\mathrm{Abs}_{\text {sample }}} \times 100
$$

Molecular docking studies: Three-dimensional coordinates COX-2 (pdb code 6-COX) were retrieved from Brookhaven Protein Data Bank. The pdb file was submitted to "Build/check/ repair model" and "Prepare PDB file for docking programs" modules where missing side chains were modelled in, a small regularization was performed, water positions and symmetry were corrected and hydrogens were added. Only chain A of the repaired pdb file was evaluated and passed to AutodockTools (ADT ver.1.5.6) for pdbqt file preparation. The ligands were constructed with ChemSketch-12.01 program and these geometries were optimized using the Austin Model 1 to the corresponding mol2 file that was submitted to ADT for pdbqt file preparation and docking with AutoDock4. The geometry of built compound was optimized, partial charges were also calculated and saved as mol2 files that was passed, as usual, to ADT for pdbqt file preparation. Autodock4 (ver. 4.2.6) [3840] was employed for docking simulations. Lamarckian genetic algorithm with local search (GALS) was used as search engine, with a total of 100 runs. The region of interest, used by Autodock4 for docking runs and by Autogrid4 for affinity grid maps preparation, was defined in such a way to comprise the whole catalytic binding site using a grid of $40 \times 40 \times 40$ points with a gridspace of $0.375 \AA$, centers of grid box: $\mathrm{x}=$ 23.049; $y=23.526 ; z=46.984$. Cluster analysis was performed on the docked results using an RMS tolerance of $2.0 \AA$. Finally, the more energetically favourable cluster poses were evaluated by using Phyton Molecule Viewer (PMV ver.1.5.6) and PyMol ver.1.7.4 (DeLano Scientific LLC).

Statistical analysis: The albumin denaturation measurement results were subjected to statistical analysis using SPSS software, Version 17 with significance at 0.05 level tested with Duncan.

\section{RESULTS AND DISCUSSION}

The target compounds (Scheme-I) were obtained by allowing ketones to react with aromatic aldehydes under basic aldol condensation conditions. The synthesis by two steps of base catalyzed Claisen condensation reaction. The first step consisted of compound vanillin with excess acetone in the presence of $\mathrm{KOH}$ (1 M) to afford the intermediate 4-(4-hydroxy3-methoxy-phenyl)-but-3-en-2-one. Then, the target compounds were prepared by Claisen condensation of 4-(4-hydroxy3-methoxy-phenyl)-but-3-en-2-one in good yield and veratraldehyde.

The site of curcumin anti-inflammatory activities is controversial among scientists. Some studies focused on the two phenol rings while others pointed it out that the $\beta$-diketone structure might be involved in the anti-inflammatory action of curcumin $[41,42]$. Previous studies have proven that the presence of bis$\alpha, \beta$-unsaturated $\beta$-diketone, two methoxy groups, two phenolic<smiles>COc1cc(C=O)ccc1O</smiles>

Vanillic aldehyde<smiles>CC(C)=O</smiles>

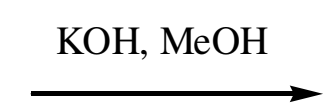

Microwave irradiation, $30 \mathrm{~s}$<smiles>COc1cc(C=CC(C)=O)ccc1O</smiles>

4-(4-Hydroxy-3-methoxy-phenyl)-but-3-en-2-one

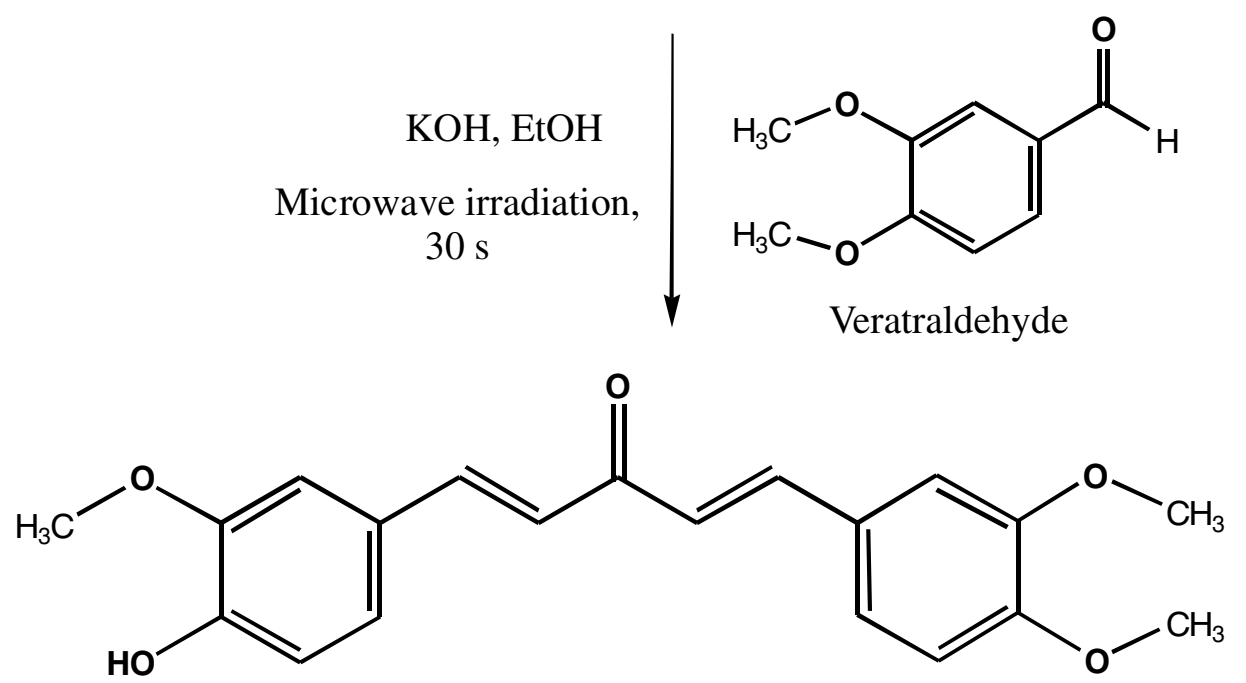

1-(3,4-Dimethoxy-phenyl)-5-(4-hydroxy-3-methoxy-phenyl)-penta-1,4-dien-3-one

Scheme-I: Synthetic routes for the asymmetric curcumin analogues 
hydroxyl groups and two double-conjugated bonds to be critical in the anti-inflammatory activities assigned to curcumin [43]. The synthesized compounds based on the structure of curcumin by eliminating the unstable $\beta$-diketone moiety and modifying it into conjugated double bonds while preserving the phenolic $\mathrm{OH}$ group. Curcumin is deemed to be a weak Michael donor since the 1,3-diketone unit in it is bis- $\alpha, \beta$ conjugated, thereby decreasing the reactivity of its central methylene unit. It is also comparatively less active as a Michael acceptor since the electron releasing substituents in its phenyl ring on both sides are in conjugation with the enone unit. The compound 1-(3,4-dimethoxy-phenyl)-5-(4-hydroxy-3-methoxyphenyl)-penta-1,4-dien-3-one has no Michael donor group. However, it is a good Michael acceptor due to its two crossconjugated to $-\mathrm{CH}=\mathrm{CH}-\mathrm{CO}-$ enone units [44]. Pharmacophore modification of the dienone functional group curcumin into monoketone and side chain of aromatic ring with asymmetrical substituents give better activity and stability than the parent compound.

Anti-inflammatory activity: In the present study the in vitro anti-inflammatory effect of compound was evaluated against the denaturation of egg albumin. The results are summarized in Table-1. The present findings exhibited a concentration dependent inhibition of protein (albumin) denaturation by the test compound throughout the concentration range of 100 to $600 \mu \mathrm{g} / \mathrm{mL}$. Dichlorofenac sodium was used as the reference drug which also exhibited concentration dependent inhibition of protein denaturation. However, the effect of dichlorofenac sodium was found to be less as compared with that of the compound.

The percentage inhibition of the synthesized compounds showed high activity against the denaturation of protein. The compound showed significant in vitro anti-inflammatory activity with \% inhibition of albumin denaturation 34.96, $62.27,68.68$ and $87.99 \%$ respectively.

The increments in absorbance of compound with respect to control indicated stabilization of protein i.e., inhibition of protein (albumin) denaturation or anti-denaturation effect by
TABLE-1

INHIBITION (\%) OF 1-(3,4-DIMETHOXY-PHENYL)-5-(4HYDROXY-3-METHOXY-PHENYL)-PENTA-1,4-DIEN-3-ONE

\begin{tabular}{ccc}
\hline \multirow{2}{*}{ Conc. $(\mu \mathrm{g} / \mathrm{mL})$} & \multicolumn{2}{c}{ Inhibition $(\%)($ Mean $\pm \mathrm{SE})$} \\
\cline { 2 - 3 } & Compound & Dichlorofenac sodium \\
\hline 100 & $34.96 \pm 0.263^{\mathrm{a}^{*}}$ & $25.30 \pm 0.173^{\mathrm{a}^{*}}$ \\
200 & $62.27 \pm 0.522^{\mathrm{b}^{*}}$ & $53.62 \pm 1.160^{\mathrm{b}^{*}}$ \\
400 & $68.68 \pm 0.185^{\mathrm{c}^{*}}$ & $69.70 \pm 0.057^{\mathrm{c}^{*}}$ \\
600 & $87.99 \pm 0.682^{\mathrm{d}^{*}}$ & $85.43 \pm 0.124^{\mathrm{d}^{*}}$ \\
\hline
\end{tabular}

*Means within two treatments that have the same letter are not signifycantly different by Duncan 0.05 test.

the compound and the reference drug dichlorofenac sodium. It has been reported that one of the features of several nonsteroidal anti-inflammatory drugs is their ability to stabilize (prevent denaturation) heat treated albumin at the physiological $\mathrm{pH}$ [45].

Molecular docking studies: The level of COX-2 inhibition of compound 1-(3,4-dimethoxy-phenyl)-5-(4-hydroxy3-methoxy-phenyl)-penta-1,4-dien-3-one prompted us to perform molecular docking studies to understand the ligandprotein interactions. For this study, the crystal structures of COX-2 enzymes complexed with SC-558 were used for the docking [46].

Fig. 1 shows the conformational superposition of SC-558 (1-phenylsulfonamide-3-trifluoromethyl-5-parabromophenylpyrazole), a selective inhibitor of COX-2 from the X-ray crystal structure of SC-558-COX-2 complex and that from the docking calculation. The RMSD between the two conformations is only $0.860 \AA$, indicating that the parameter set for docking is capable of reproducing the X-ray structure.

The most stable docking model was selected according to the best scored conformation predicted by the AutoDock scoring function. The compound 1-(3,4-dimethoxy-phenyl)5-(4-hydroxy-3-methoxy-phenyl)-penta-1,4-dien-3-one was found to dock into the active site of COX-2 protein (PDB code: $6 \mathrm{COX}$ ) with interaction energy of $-7.6 \mathrm{kcal} / \mathrm{mol}$. The compound could dock into the active site of COX-2 successfully. The compound produces a deep moving into the hydrophilic
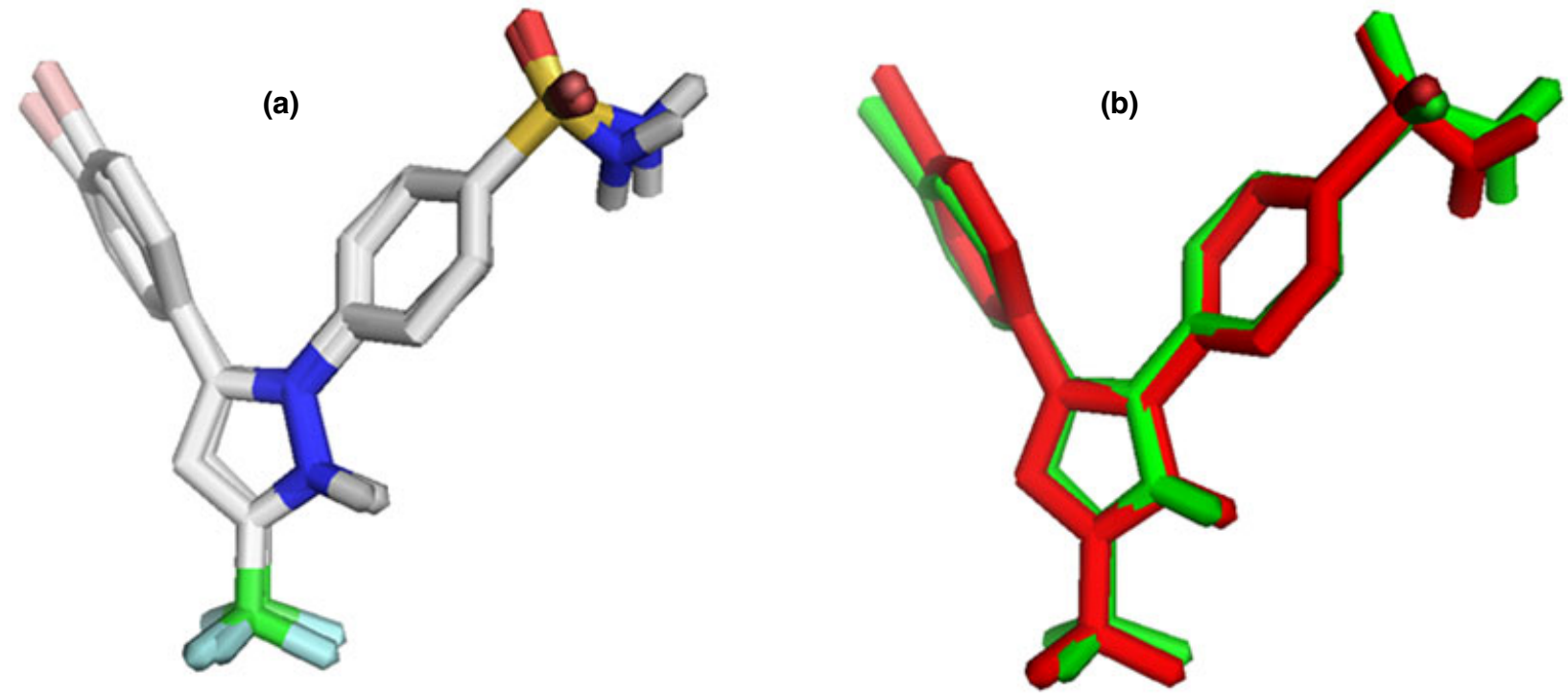

Fig. 1. (a) Conformational comparison of SC-558, (b) Crystal structure of SC-558-COX-2 complex (green) and that from the docking simulation (red) 
pocket of COX-2 with which the methoxy groups are able to reach the hydrophilic pocket and is involved in hydrogen bonding with $\operatorname{His}^{90}(2.2,3.3 \AA)$ and $\operatorname{Arg}^{120}(2.2,2.3 \AA)$. Such interactions are almost essential for COX-2 inhibitory activity, as exemplified by the binding interaction of SC-558, an analog of celecoxib cocrystallized in the COX-2 active site [47,48].

Docking studies in COX-2 showed that the methoxyphenyl ring of compounds fitted into the hydrophobic cavity formed by $\mathrm{Met}^{552}, \mathrm{Arg}^{513}, \mathrm{Tyr}^{385}, \mathrm{His}^{90}, \mathrm{Tyr}^{348}$ and $\mathrm{Ser}^{530}$. In the crystal structure of COX-2, this hydrophobic cavity was occupied by bromophenyl ring of SC-558. The compounds were oriented so that their methoxyphenyl group fitted into the adjunct pocket which is responsible for COX-2 inhibitory activity. The oxygen atom of methoxy group of compounds formed weak bonds with $\mathrm{Arg}^{513}$ and $\mathrm{His}^{90}$ approximately at distances of 3.8 and 3.3 Å respectively. Furthermore, hydrogen bonds were observed between $\mathrm{Arg}^{120}$ and $\mathrm{C}=\mathrm{O}$ group of compounds at distances of 2.2 and 2.3 A respectively (Fig. 2).

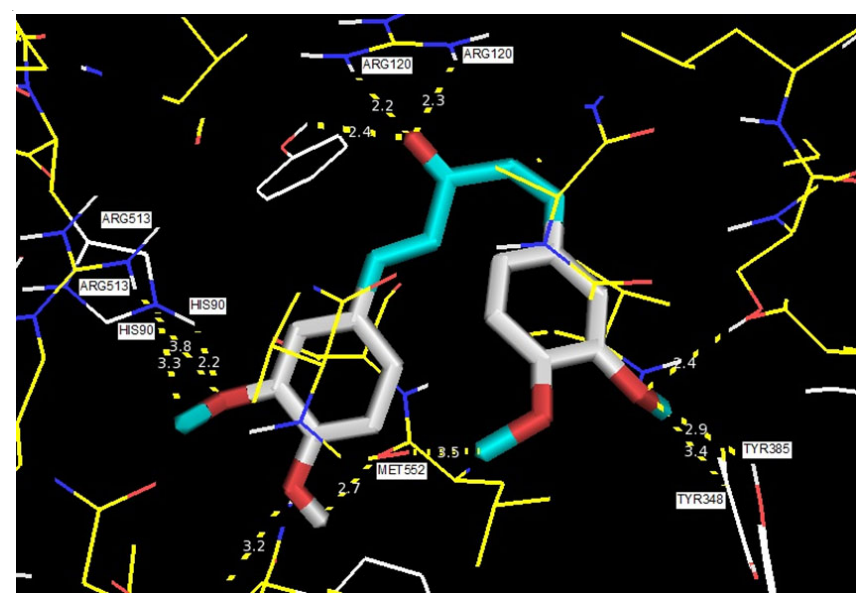

Fig. 2. Docked view of the synthesized compound on anti-inflammatory target COX-2 (PDB ID: 6COX)

The greater interaction energy of compound and COX-2 enzyme complex rationalizes the tighter binding of compound into the COX-2 active site and this binding may be attributed to its nine hydrogen bonding interactions with $\mathrm{Tyr}^{385}, \mathrm{Phe}^{518}$, $\mathrm{Leu}^{351}, \mathrm{Arg}^{513}, \mathrm{His}^{90}, \mathrm{Tyr}^{335} \mathrm{Arg}^{120}$ and $\mathrm{Ser}^{530}$. The bonding distance between $-\mathrm{OCH}_{3}$ of compound with $-\mathrm{OH}$ of $\mathrm{Tyr}^{385} 2.9 \AA \mathrm{\AA}(\mathrm{H} \cdots \mathrm{O})$; - $\mathrm{OH}$ of compound and - $\mathrm{OH}$ of $\mathrm{Phe}^{518} 3.2 \AA$ (H...O); - $\mathrm{OH}$ of compound and - $\mathrm{OH}$ of $\mathrm{Leu}^{351} 2.7 \AA(\mathrm{H} . . \mathrm{O})$; - $-\mathrm{OCH}_{3}$ of compound and - $\mathrm{NH}$ of $\mathrm{Arg}^{513} 3.8 \AA$ ( $\left.\mathrm{N} \ldots \mathrm{O}\right)$; - $-\mathrm{OCH}_{3}$ of compound and - $\mathrm{NH}$ of $\mathrm{His}^{90} 3.3 \AA$ (N...O); $\mathrm{C}=\mathrm{O}$ of compound and $-\mathrm{OH}$ of $\mathrm{Tyr}^{355} 2.4 \AA$ (H...O) $\mathrm{C}=\mathrm{O}$ of compound and - $\mathrm{NH}$ of $\mathrm{Arg}^{120}$ $2.3 \AA(\mathrm{N} . . \mathrm{O})$ and $-\mathrm{OCH}_{3}$ of compound and $-\mathrm{OH}$ of $\mathrm{Ser}^{530} 2.4$ $\AA$ (H...O) of COX-2 were observed (Fig. 2). Molecular docking studies further helped in understanding the binding orientation of ligands at the active site of enzyme and substantiated the observed COX-2 inhibition in vitro.

\section{Conclusion}

In summary, we have reported a simple and efficient method for the synthesis of 1-(3,4-dimethoxy-phenyl)-5-(4-hydroxy3-methoxy-phenyl)-penta-1,4-dien-3-one curcumin analogues with excellent yield. In the newly synthesized compounds were found to have good anti-inflammatory activity. The compound showed good inhibitory anti-inflammatory activity against the denaturation of protein method. The molecular docking results showed that the compound possess anti-inflammatory property.

\section{REFERENCES}

1. J.G. Black, Microbiology Principles and Explorations, Wiley, edn 2 (2012).

2. S.M. Jachak, Curr. Med. Chem., 13, 659 (2006); https://doi.org/10.2174/092986706776055698.

3. L.J. Marnett and A.S. Kalgutkar, Trends Pharmacol. Sci., 20, 465 (1999); https://doi.org/10.1016/S0165-6147(99)01385-1.

4. G. Dannhardt and W. Kiefer, Eur. J. Med. Chem., 36, 109 (2001); https://doi.org/10.1016/S0223-5234(01)01197-7.

5. J.R. Vane, Y.S. Bakhle and R.M. Botting, Annu. Rev. Pharmacol. Toxicol., 38, 97 (1998);

https://doi.org/10.1146/annurev.pharmtox.38.1.97.

6. O. Laneuville, D.K. Breuer, D.L. DeWitt, T. Hla, C.D. Funk and W.L. Smith, J. Pharmacol. Exp. Ther, 271, 927 (1994).

7. D.A. Kujubu, B.S. Fletcher, B.C. Varnum, R.W. Lim and H.R. Herschman, J. Biol. Chem., 266, 12866 (1991).

8. L.J. Crofford, J. Rheumatol. Suppl., 49, 15 (1997).

9. K. Seibert, Y. Zhang, K. Leahy, S. Hauser, J. Masferrer, W. Perkins, L. Lee and P. Isakson, Proc. Natl. Acad. Sci. USA, 91, 12013 (1994); https://doi.org/10.1073/pnas.91.25.12013.

10. N.S. Buttar and K.K. Wang, Mayo Clin. Proc., 75, 1027 (2000); https://doi.org/10.4065/75.10.1027.

11. C. Michaux and C. Charlier, Mini Rev. Med. Chem., 4, 603 (2004); https://doi.org/10.2174/1389557043403756.

12. R.K. Maheshwari, A.K. Singh, J. Gaddipati and R.C. Srimal, Life Sci., 78, 2081 (2006); https://doi.org/10.1016/j.lfs.2005.12.007.

13. A.J. Ruby, G. Kuttan, K. Dinesh Babu, K.N. Rajasekharan and R. Kuttan, Cancer Lett., 94, 79 (1995); https://doi.org/10.1016/0304-3835(95)03827-J

14. L.N. Grinberg, O. Shalev, H.H. Tønnesen and E.A. Rachmilewitz, Int. J. Pharm., 132, 251 (1996); https://doi.org/10.1016/0378-5173(95)04377-2

15. M.M.-Y. Chan, C.-T. Ho and H.-I. Huang, Cancer Lett., 96, 23 (1995); https://doi.org/10.1016/0304-3835(95)03913-H.

16. M.M.-Y. Chan, H.-I. Huang, M.R. Fenton and D. Fong, Biochem. Pharmacol., 55, 1955 (1998);

https://doi.org/10.1016/S0006-2952(98)00114-2.

17. H. Inano, M. Onoda, N. Inafuku, M. Kubota, Y. Kamada, T. Osawa, H. Kobayashi and K. Wakabayashi, Carcinogenesis, 21, 1835 (2000); https://doi.org/10.1093/carcin/21.10.1835.

18. R. Thapliyal and G.B. Maru, Food Chem. Toxicol., 39, 541 (2001); https://doi.org/10.1016/S0278-6915(00)00165-4.

19. C.A.C. Araujo, L.V. Alegrio, D.C.F. Gomes, M.E.F. Lima, L. GomesCardoso and L.L. Leon, Mem. Inst. Oswaldo Cruz, 94, 791 (1999); https://doi.org/10.1590/S0074-02761999000600015.

20. A. Mazumder, K. Raghavan, J. Weinstein, K.W. Kohn and Y. Pommier, Biochem. Pharmacol., 49, 1165 (1995); https://doi.org/10.1016/0006-2952(95)98514-A.

21. T.P. Robinson, R.B. Hubbard IV, T.J. Ehlers, J.L. Arbiser, D.J. Goldsmith and J.P. Bowen, Bioorg. Med. Chem., 13, 4007 (2005); https://doi.org/10.1016/j.bmc.2005.03.054.

22. Z. Du, R. Liu, W. Shao, X. Mao, L. Ma, L. Gu, Z. Huang and A.S.C. Chan, Eur. J. Med. Chem., 41, 213 (2006); https://doi.org/10.1016/j.ejmech.2005.10.012.

23. S.-Y. Park and D.S.H.L. Kim, J. Nat. Prod., 65, 1227 (2002); https://doi.org/10.1021/np010039x.

24. J. Ishida, H. Ohtsu, Y. Tachibana, Y. Nakanishi, K.F. Bastow, M. Nagai, H.-K. Wang, H. Itokawa and K.-H. Lee, Bioorg. Med. Chem., 10, 3481 (2002); https://doi.org/10.1016/S0968-0896(02)00249-3.

25. Y. Jiao, J. Wilkinson IV, E. Christine Pietsch, J.L. Buss, W. Wang, R. Planalp, F.M. Torti and S.V. Torti, Free Radic. Biol. Med., 40, 1152 (2006); https://doi.org/10.1016/j.freeradbiomed.2005.11.003.

26. G. Gilli and V. Bertolasi, ed: Z. Rppoport, The Chemistry of Enols, John Wiley \& Sons, New York, p. 713 (1990).

27. S.V. Jovanovic, C.W. Boone, S. Steenken, M. Trinoga and R.B. Kaskey, J. Am. Chem. Soc., 123, 3064 (2001); https://doi.org/10.1021/ja003823x. 
28. D. Thaloor, A.K. Singh, G.S. Sidhu, P.V. Prasad, H.K. Kleinman and R.K. Maheswari, Cell Growth Differ., 9, 305 (1998).

29. J.L. Arbiser, N. Klauber, R. Roghan, R. Vanleeuwen, M.T. Huang, C. Fisher, E. Flynn and H.R. Byers, Mol. Med., 4, 376 (1998).

30. S.V. Jovanovic, S. Steenken, C.W. Boone and M.G. Simic, J. Am. Chem. Soc., 121, 9677 (1999); https://doi.org/10.1021/ja991446m.

31. K. Balasubramanian, J. Agric. Food Chem., 54, 3512 (2006); https://doi.org/10.1021/jf0603533.

32. A.M. Alanazi, A.S. El-Azab, I.A. Al-Suwaidan, K.E.H. El-Tahir, Y.A. Asiri, N.I. Abdel-Aziz and A.A.-M. Abdel-Aziz, Eur. J. Med. Chem., 92, 115 (2015); https://doi.org/10.1016/j.ejmech.2014.12.039.

33. A.S. Kalgutkar, B.C. Crews, S.W. Rowlinson, C. Garner, K. Seibert and L.J. Marnett, Science, 280, 1268 (1998); https://doi.org/10.1126/science.280.5367.1268.

34. M.R. Sohilait, H.D. Pranowo and W. Haryadi, Bioinformation, 13, 356 (2017); https://doi.org/10.6026/97320630013356.

35. M.G.R. Priya, K. Girija and N. Ravichandran, Rasayan J. Chem., 4, 418 (2011).

36. K.S. Kumar, V. Maheshwaran, T.D. Rao, K. Themmila, M.N. Ponnuswamy, S. Kadhirvel and S. Dhandayutham, J. Mol. Struct., 1146, 314 (2017); https://doi.org/10.1016/j.molstruc.2017.05.085.

37. U. Sahoo, A.K. Seth, R. Balaraman and R. Velmurugan, Asian J. Chem., 27, 961 (2015); https://doi.org/10.14233/ajchem.2015.17788.

38. G.M. Morris, R. Huey, W. Lindstrom, M.F. Sanner, R.K. Belew, D.S. Goodsell and A.J. Olson, J. Comput. Chem., 30, 2785 (2009); https://doi.org/10.1002/jcc.21256.

39. M.K. Paul and A.K. Mukhopadhyay, Int. J. Med. Sci., 1, 101 (2004); https://doi.org/10.7150/ijms.1.101.
40. G.M. Morris, D.S. Goodsell, R.S. Halliday, R. Huey, W.E. Hart, R.K. Belew and A.J. Olson, J. Comput. Chem., 19, 1639 (1998); https://doi.org/10.1002/(SICI)1096-987X(19981115)19:14<1639:: AID-JCC10>3.0.CO;2-B

41. Z. Liu, L. Tang, P. Zou, Y. Zhang, Z. Wang, Q. Fang, L. Jiang, G. Chen, Z. Xu, H. Zhang and G. Liang, Eur. J. Med. Chem., 74, 671 (2014); https://doi.org/10.1016/j.ejmech.2013.10.061.

42. J. Wu, Y. Zhang, Y. Cai, J. Wang, B. Weng, Q. Tang, X. Chen, Z. Pan, G. Liang and S. Yang, Bioorg. Med. Chem., 21, 3058 (2013); https://doi.org/10.1016/j.bmc.2013.03.057.

43. S.K. Sandur, M.K. Pandey, B. Sung, K.S. Ahn, A. Murakami, G. Sethi, P. Limtrakul, V. Badmaev and B.B. Aggarwal, Carcinogenesis, 28, 1765 (2007); https://doi.org/10.1093/carcin/bgm123.

44. P. Anand, B. Sung, A.B. Kunnumakkara, K.N. Rajasekharan and B.B. Aggarwal, Biochem. Pharmacol., 82, 1901 (2011); https://doi.org/10.1016/j.bcp.2011.09.001.

45. V.A. Jagtap, Y.S. Agasimundim, E. Jayachandran and B.S. Sathe, J. Pharm. Res., 4, 378 (2011).

46. M. Anzini, M. Rovini, A. Cappelli, S. Vomero, F. Manetti, M. Botta, L. Sautebin, A. Rossi, C. Pergola, C. Ghelardini, M. Norcini, A. Giordani, F. Makovec, P. Anzellotti, P. Patrignani and M. Biava, J. Med. Chem., 51, 4476 (2008) https://doi.org/10.1021/jm800084s.

47. R.G. Kurumbail, A.M. Stevens, J.K. Gierse, J.J. McDonald, R.A. Stegeman, J.Y. Pak, D. Gildehaus, J.M. iyashiro, T.D. Penning, K. Seibert, P.C. Isakson and W.C. Stallings, Nature, 384, 644 (1996); https://doi.org/10.1038/384644a0.

48. J.L. Wang, D. Limburg, M.J. Graneto, J. Springer, J.R.B. Hamper, S. Liao, J.L. Pawlitz, R.G. Kurumbail, T. Maziasz, J.J. Talley, J.R. Kiefer and J. Carter, Bioorg. Med. Chem. Lett., 20, 7159 (2010); https://doi.org/10.1016/j.bmcl.2010.07.054. 